\title{
Management of IFES in Brazil in the Thesis and Dissertations of Capes
}

\author{
Mara Aguida Porfírio Moura (MSc) \\ Guiomar de Oliveira Passos (Dr. ${ }^{a}$ )
}

Universidade Federal do Piauí - UFPI, Piauí - Brasil

doi: 10.19044/esj.2017.v13n25p30 URL:http://dx.doi.org/10.19044/esj.2017.v13n25p30

\begin{abstract}
The results of the survey carried out in Banco de Teses e Dissertações da Coordenação da CAPES (Thesis and Dissertation Bank of CAPES Coordination) on the management of Brazilian universities after the Reuni are presented, with the objective of verifying an approach to the subject and its results. To do so, 59 papers were selected, only 22 (3 theses and 19 dissertations) deal with a study on the results of the Reuni Program. It is verified that management is dealt with in just 2 works, and the others are related to planning and implementation of Reuni in a particular institution, teaching, program financing, and expansion of under graduation, organizational socialization, access, efficiency assessment, curricular restructuring and student assistance. It is concluded that management is a secondary topic on thesis and dissertations and that the approaches turn to the effects of the foreseen model, sometimes trying to reach the goal of the Program to expand opportunities to access, sometimes administration of Academic units.
\end{abstract}

Keywords: University management. Under Graduation. REUNI

\section{Introduction}

The text presents the results of the survey conducted at the Bank of Thesis and Dissertations of the Coordination of Improvement of Higher Education Personnel (CAPES) on the management of federal universities after Reuni with the goal of verifying the approach of the subject and its results. It is an effort of interpretation driven by two intentions: the first is to identify the theoretical-methodological procedures used by understanding that it may prove useful for other researches. The second is to verify what the results showed by gathering elements to evaluate the results of Reuni on the management of participating institutions. 
It is that, according to art. 1st of Decree 6,096 / 2007, was "for the best use of the physical structure and human resources existing in federal universities" that the Program aimed to "create conditions for the expansion of access and permanence in under graduation courses [...] "(Brazil, 2007). This way, it linked the expansion of under graduation to efficiency and effectiveness in the use of financial, material and human resources.

Efficiency and effectiveness are themes that come to appear in public policies with the 1995 Public Management Reform (Pereira, 1998). Guided by the ideals of decision-making management, the Reform elected, along with the institutional and legal dimension and the cultural dimension, the management dimension, partially replacing the rigid regulations of supervision and auditing, which characterize bureaucratic administration, "for greater autonomy" and "manager accountability ", especially through the following mechanisms: "management by results, managed competition per excellence, and social control" (Pereira, 1998).

If, on one hand, it meant "a profound modification of the Weberian model classified as slow and excessively attached to norms" (Abrucio, 1997, p.10), on the other hand, it brought to the center of the debate the way of leading the State, or, in other words, the management of State action. The transformation of the public administration, which began in England by Margaret Thatcher, spread around the world and arrived in Brazil with the Collor Administration, which used, as in other countries, the antibureaucratic chord expressed in the struggle against the 'Maharajas', promoted a restructuring of the public machine "which, instead of modernizing it and, above all, reducing it, as was the intent, led to its dismantling (Abranches, 1992, 154).

The reforming idea gained more support with the Fernando Henrique Cardoso administration. This way, by supporting not only on the diagnosis of the Brazilian public administration since the 1930s, but also on international experiences, especially on the English one, promoted with the sign of Leading Plan of State Reform (Plano Diretor da Reforma do Estado), there was "administrative reorganization of federal government" and a wide constitutional review on which the "introduction of efficiency principle among the pillars of Administrative Law" was remarked (Abrucio, 2007, p. 71). Besides, as Abrucio explains (2007), it spread "a rich debate on a federal plan and states about new ways of management strongly guided to the improvement of performance on the public division". (p.71).

On Reuni, the Lula administration, despite its "inability to establish an agenda for public management reform" (Abrucio, 2007: 77), expressed its stated objective of "increasing the effectiveness of public policies, especially the social ones, without harming the necessary fiscal adjustment"(Abrucio, 2007, p.77) and to search for the efficiency already announced in the Public 
Management Plan of a Brazil for All (Plano de Gestão Pública de um Brasil de Todos) as a means of" doing more and better with the resources available ... " (Brasil, 2003, p.10).

What is examined in this text is whether the management debate has slipped into the academic field regarding the management of universities after Reuni, given the importance of efficiency to achieve its goal.

First, the presence of the subject is verified in dissertations and theses available in the Bank of Theses of Capes, and then the way in which it was approached and the appropriate findings.

The work is exploratory and descriptive with a qualitativequantitative approach using technical documental research procedures and categorical content analysis based on Bardin's (2011) indications. The corpus of analysis were the theses and dissertations available on the Thesis Bank of the Coordination for the Improvement of Higher Education Personnel (Capes) between 2011 and 2014.

The search was done, first, at http://bancodeteses.capes.gov.br/, option "basic search", the works through the expression "Program Reuni" being selected. Then, from the abstracts and introductions, those which aimed to study Reuni Program were chosen, identifying, from a categorical analysis, the subject addressed from which those dealing with the management theme were selected. In these, from a new categorical analysis, the way in which the examination was carried out and the findings were verified.

The results are presented in three sections among which the present introduction is the first one. The second section characterizes the selected papers in terms of: the year in which the surveys were conducted; the courses in which they were developed; its objectives and focused aspects, detailing those that focused management in terms of perspective of analysis and findings. Finally, the theoretical-methodological procedures used and the verifications are analyzed.

\section{Reuni in selected theses and dissertations}

The 22 papers that make up the corpus of this research were presented between 2011 and 2014. It can be seen, according to Table 1, that the studies started in the first years of the Program's implementation, but the most (72\%) between 2009 And 2010. 
Table 1: Beginning of researches/ Number of selected Works. Absolute value: abs.

\begin{tabular}{ccc}
\hline Year & Abs. & $\%$ \\
\hline 2008 & 1 & 5 \\
2009 & 8 & 36 \\
2010 & 8 & 36 \\
2011 & 2 & 9 \\
2012 & 3 & 14 \\
\hline TOTAL & 22 & 100 \\
\hline
\end{tabular}

Source: Authors' elaboration

The study of the Program then occurred pari passu for its implementation, which may explain not having the results of the intervention as object, that is, the impacts or effects caused in the social or institutional environment (Cohen \& Franco, 1993; Cotta 1998; Draibe , 2001), even if it has been approached, as shown in Table 2, in courses in the area of Education, Administration, Accountancy, Public Policy Assessment, Social Policy or Interdisciplinary.

Table 2: Areas of courses in which the works are connected to. Absolute Value: abs.

\begin{tabular}{ccc}
\hline Areas & Abs. & $\%$ \\
\hline Education & 16 & 73 \\
Administration & 2 & 9 \\
Accountancy & 1 & 5 \\
Public Polícy Assessement & 1 & 5 \\
Social Polícy & 1 & 5 \\
Interdisciplinary & 1 & 5 \\
\hline TOTAL & 22 & 100 \\
\hline
\end{tabular}

Source: Authors' elaboration from results after work selection.

The diversity of areas is reflected upon the objectives that, as shown in Table 3, were mainly focused on analyzing (50\%) and evaluating (23\%) by indicating that the interest was in understanding the policy and judging its applications and also in measuring its performance.

Table 3: Research goals. Absolute Value: abs.

\begin{tabular}{ccc}
\hline Goalss & Abs. & $\%$ \\
\hline Analyze & 11 & 50 \\
Assess & 5 & 23 \\
Outline/Identify & 3 & 14 \\
Study & 1 & 5 \\
Present & 2 & 9 \\
\hline TOTAL & 22 & 100 \\
\hline
\end{tabular}

Source: Authors' elaboration from results after work selection. 
This is evidenced by the fact that the aspects focused on the goals presented on Table 4 were mainly access to under graduation (32\%), management $(23 \%)$, organizational structure $(23 \%)$, teaching $\%$ ) and student assistance $(5 \%)$.

Table 4: Approached Themes. Absolute Value: Abs.

\begin{tabular}{ccc}
\hline Theme & Abs. & $\%$ \\
\hline Access to under graduation & 7 & 32 \\
Management & 5 & 23 \\
Organizational Structures & 5 & 23 \\
Teaching & 4 & 18 \\
Student assistance & 1 & 5 \\
\hline TOTAL & 22 & 100 \\
\hline
\end{tabular}

Source: Authors' elaboration from the results after work selection.

The concern about the goal of the Program is the expansion of under graduation by examining it in relation to the access and permanence of the student in under graduation and the teaching work. Among those who have turned to access, there are studies by Arruda (2011) and Araújo (2011). The first objective was to "analyze the Reuni Program in terms of expanding access opportunities for students with socioeconomic and educational disadvantages, with a low participation in this level of schooling" (Arruda, 2011, p.25), and the second, "investigate the outcomes of the Program on the aspects related to access to under graduation, financing and university management "(Araújo, 2011, p.7).

The permanence was focused by Coelho (2012, p.7) who wanted to "understand the relevance of this program during student assistance as an acquired social right by observing the relation between the real needs of the students and the services offered by the State." The teaching work was Gregorio's focus (2011, p.14), who analyzed "the theoretical bases of the actions of the federal government in relation to the teaching work in the IFES by considering the specific case of UFU, mainly after the Presidential Decree that instituted Reuni ".

This theme was also developed by Coelho $(2012$, p.9) in order to:

Study the processes of university teaching towards the public policies that underlie the guidelines, practices and strategies of teacher training in public universities, especially the Federal University of Minas Gerais - UFMG, with the implementation of the Reuni Program created through Decree No. 6,096, of April 24, 2007. 
Another aspect addressed in the studies was the effects of Reuni on the organizational structure of under graduation institutions and management. The program also turned to the restructuring of universities which provoked controversy, debate and opposition, as evidenced by the "Campaign for the Revocation of Presidential Decree No. 6,096" organized by the National Coordination of Entities for the Revocation of REUNI (2009) and The Public Hearing held by the Education Commission of the Federal Senate (2009).

The organizational structure of the institutions was also studied by Andrade (2011, page 22) with the intention of "identifying the perception of the servers about the level of organizational socialization and evaluating whether there are differences between administrative servers and teachers in relation to Reuni Program." Another writer with this concern was Silva (2011, p.5) when analyzing the Institutional Plans prepared by the IFES of MS toward the explanation of their configurations from the guidelines of Reuni program in the national context.

Management was approached from a planning perspective which evaluates "the process of planning and implementation of Reunion Program at IFES in Minas Gerais" (Lugão, 2011, p.4) and also under the focus of the challenges of expansion for managers. This was the study by Silva (2013, p.7) that aimed to "analyze the main challenges faced by managers of UFJF academic units toward the expansion of institutions with the expansion of access to under graduation provided by Reuni."

It also involved the study by Pereira (2012) by "analyzing the implementation of Reuni Program and its role in the reconfiguration of UFRN emphasizing its repercussion in the management and organization of the university" (Pereira, 2012, p. Oliveira (2013), who investigated "the influence of Reuni on the efficiency of Brazilian IFES in two distinct moments considering Pre-Reuni period (2006-2007) and Reuni (2008-2012)" (Oliveira, 2013, p.12). Such studies make it possible to verify the effects of Reuni on the management and, consequently, offer elements to understand the results of this Program on the Federal Institutions of Education. In them, it is examined how they focused on the object and what they found.

\section{Perspectives on REUNI analysis and results in the studies on the effects of the Program on the management of IFES.}

The study by Pereira (2012), developed in an Education Program, considers that Reuni "is managerial in character and that it establishes goals to be fulfilled by the institutions that follow it" (Pereira, 2012, p.17). Thus, from historical-dialectical materialism, the author examines the object from three dimensions: policies for under graduation, the restructuring of management and the expansion of under graduation (Pereira, 2012, p.21). 
The first, by placing under graduation policy in the context of "current forms of State organization, education, the meaning of citizenship toward the structural framework of investment" (Pereira, 2012, 22), analyzes how changes in the role of the State provoked by globalization and liberal ideas had repercussions on the policy of under graduation set up in Reuni.

The second involves the transition from the bureaucratic management model to the managerial one which, based on the principle of accountability, emphasizes the performance and results agreed in the contract (Pereira, 2012). In the third section, the expansion of under graduation is examined by considering, on one hand, "the need to universalize access ..." (Pereira, 2012, page 22) and the guiding principles of Reuni, and, on the other, the effectiveness of this at the Federal University of Rio Grande do Norte.

By doing so, it can be seen from documentary sources and interviews that Reuni made it possible for UFRN to maintain the expansionist process introduced in mid 1990s with courses at night, postgraduate and new training models, for instance, the Bachelor's degree in Science and Technology. This, which was the "differential aspect of the UFRN's Project for Reuni", would allow, he explains, "the formation of a generalist bachelor who [could] enter the labor market and also automatically enroll in Engineering or Exact Sciences courses for their professional training in two years "(Pereira, 2012, p.146).

Such innovation implied not only academic-curricular restructuring but also the creation of a Specialized Academic Unit along with Managing Committees responsible for managing the available scholarship grants by the Program and the established goals. The work does not expose the actions carried out by these committees, nor even by those who, with an Academic and Administrative Coordination, were responsible for the achievements of the goals by exercising "the function of control, supervision and evaluation" (Pereira, 2012, p. 148).

Actually, the theme of management is focused on the context of the State Reform of the 1990s which added to the reduction in the size of the State, the focus of those working between 1970 and 1990, "the need for change in the public administration to make it more efficient [...] "(Pereira, 2012, p.39) as means of crisis overcoming of the capitalist State that began in the 1970s. This change is based on the paradigm, no longer of classical managerialism but of the "New public management" that, according to the writer, is characterized by the reorganization of the organizational structure of the public administration and by the concern with "the processes and results of public policies, based on examples of efficiency, effectiveness and productivity "(Pereira, 2012 , Pp. 51-52), the basis of which is the management contract. 
This would be arranged in Reuni, which, with the pursuit of goals, by using the management contract as an instrument and the focus on efficiency and flexibility, led to a change in the dominant organizational culture that time in universities, which showed "to be coordinated with the proposals for managerial innovations of State reform (Pereira, 2012, page 132). Reuni, says Pereira (2012, pp. 150-151):

It does not present itself only as a Plan to expand access and optimization of the performance indexes of federal universities, but as a new managerial logic of education influenced by the general principles of State Reform implemented by Bresser Pereira.

At Federal University of Rio Grande do Norte, according to the author (Pereira, 2012, p. 166), "Reuni brought a series of modifications to the organizational culture" evidenced in a new management practice that aims to follow the goals and performance indicators of the institution. (Pereira, 2012, p.166), "it grudges no pains to achieve the agreement with MEC in the management plans by placing the search for efficiency and effectiveness as central to the detriment of the education offered."

Definitely, according to Pereira (2012), UFRN consolidated its expansion process started in the Fernando Henrique Cardoso Administration "with the construction of a basic structure [and] improvement of the physical conditions of the institution", creation of new courses, mostly at night and a "substantial increase in the relation between teacher and student" by evidencing the rationalization of human resources and the existing physical structure, as the Program required (Pereira, 2012, 175).

This, to the author, "implicitly brings a pretense of disowning the role of the State by characterizing its 'new' function of coordinating and controlling the execution [of] the policies at the macro level ", in which participation and autonomy are playing the role of State with unpredictable impacts "on the quality of education offered" (Pereira, 2012, pp. 175-176).

It is observed that the perspective adopted is to highlight the limitations of the management model identified in Reuni Program to carry out the tasks of promoting well-being which is, conclusively, the role of the State in the author's view.

The work by Oliveira (2013), developed within the framework of a Graduate Program in Accountancy, focuses on investments meant to under graduation from 2008 to 2012, from 56.5\% in 2005, to 93\% during Reuni Program. This work explores the efficiency of institutions before (20062007) and after Reuni (2008 to 2012) from the perspective of production theory which, as a branch of economic theory, specifies "the way in which inputs influence outputs "(Oliveira, 2013, p.18) in any production, including education. 
The link "between a series of inputs to the educational process and its product" (Oliveira, 2013, p.19) in education is shown under two approaches: "evaluation of the quality of teaching by focusing on the evaluation of the development of the student [...] and the second in the assessment of the quality of schooling concentrated on the consolidated structure of the different universities "(Oliveira, 2013, p.20).

On the first approach, the inputs were "study time" and "student training resources", and the products: "achievements after training", such as: "number of students employed", "quantity of entering students in graduation courses (when the evaluation is done in universities) ". In the second approach, the results are: "amount of research developed by the institution", "publication", "teacher qualification" and "number of students" (Oliveira, 2013, p.20). In both cases, he concludes, "the focus is on investigating efficiency among educational institutions."

For this, it uses the "non-parametric statistical technique of Data Envelopment Analysis [DEA]" which allows not only "a multifaceted analysis of efficiency" of inputs and outputs (Oliveira, 2013, p.14), but also "compare and measures the efficiency of the IFES, as well as ranks according to their level of efficiency "(Oliveira, 2013, page 58). To this, the performance indicators established by the TCU through Decision no. $408 / 2002$ were submitted and published in the management reports of the universities annually, according to whether they were input or output.

The first types, for the author (Oliveira, 2013, p.63), are: Current cost with university hospital / student equivalent; Current cost without university hospital / student equivalent; Full-time student / equivalent teacher, Full-time student / equivalent employee with university hospital; Full-time student / equivalent employee without university hospital; Degree of student participation (GPE/ DSP); Degree of student involvement with postgraduate (GEPG/ DSIPG); Faculty qualification index (IQCD/ FQI). The second types are: CAPES / MEC Concept for postgraduate and Graduation Success Rate (TSG/GSR).

The analysis carried out before and after Reuni showed that "average efficiency was decreasing over the years with a more significant reduction in the period from 2008 to 2009 and stabilizing until 2012, (Oliveira, 2013, p.105), which are examples: the increase in the current cost per student equivalent and the proportion of teachers and staff in relation to the number of students.

However, it was established that the circumstance varies among the IFES with some being more efficient than others as shown in the ranking based on the management indicators submitted to the DEA. In this ranking, in the seven years analyzed, the Federal University of Minas Gerais reached the first place in 4 years and the Federal University Fluminense was the last 
in the same period. In the last positions, however, "on the basis of the metric of the average Euclidean distance" (Oliveira, 2013, p. 110), the Federal University of Rio de Janeiro and, lastly, the Fluminense Federal University.

The management here is not examined as a theoretical category, but as a 'modus operandi' in which efficiency, for which the study is turned to, is one of the attributes. It is therefore a different perspective from the previous work, but also focused on the influence of Reuni in the conduct of IFES.

\section{Final considerations}

This research presents the results on REUNI Program in the publications of the Thesis and Dissertations Database of the Coordination of Improvement of Under Graduation Personnel (CAPES) between 2011 and 2014 with the analysis of 22 papers (3 theses and 19 dissertations) that constitute the corpus of this study.

It was identified that $72 \%$ of the research started in 2009 and 2010, evidencing the interest in the Program and the measurement of the results or preliminary impacts presented by the institutions through the publication of the management reports of each IFES. Most of them (73\%), produced in Postgraduate Programs in Education with the objective of analyzing or evaluating the Program, first demonstrated an interest in understanding the policy and then judging its results or its effects on access to higher education and the management of educational institutions.

The connection between management and Reuni Program is not a dominant focus of the studies as it appears in only two of the selected papers (less than 10\%), one analyzing it in the context of State Reform and the other as a modus operandi, whose efficiency to which the study turns to, is one of the attributes. The first one finds that Reuni provoked changes in organizational culture and management practices in the Federal University of Rio Grande do Norte in order to reach to an agreement with MEC, but, warns the author, its effects on education quality cannot be predicted.

The second one found that the average efficiency of institutions declined over the years, being more significant in the first post-Reuni years (2008 - 2009), and holds stable from 2010. This is, however, not uniform among IFES, with some more efficient than others, such as: the Federal University of Minas Gerais first in efficiency and the Federal University of Fluminense, the last.

Thus, although under different perspectives, they revealed the difficulties of implementing the Program's strategy to achieve its goal of increasing access through the efficient use of human and physical resources. Therefore, rather than explaining the limits of the Program, they show that the theme, although present in the debates in the university and academic 
community, did not become the object of attention of masters and doctoral students.

Perhaps because the management theme as understood in the framework of the Reformation of the State and, consequently, of the proclaimed neoliberalism, is not perceived as important, in the words of Bourdieu (1994, 125), as possible "to make appear who produces it as important and interesting in the eyes of the public ". It is hoped that this will not occur by broadening or deepening the problems that Reuni proposed to solve, especially inefficiency in the use of public resources.

\section{References:}

1. Abranches, S. (1992). O Estado. In: H. Jaguaribe. Sociedade, Estado e partidos na atualidade brasileira. Rio de Janeiro, RJ: Paz e Terra.

2. Abrucio, F. L. (1997). O impacto do modelo gerencial na administração pública: um breve estudo sobre a experiência internacional recente. Brasília, DF: Cadernos ENAP.

3. Abrucio, F. L. (2007, n.spe). Trajetória recente da gestão pública brasileira: um balanço crítico e a renovação da agenda de reformas. RAP, v.41, pp.67-86. Rio de Janeiro, RJ: RAP.

4. Andrade, D. C. T. (2011). Socialização organizacional em uma IFES mineira em tempos de Reuni. Dissertação de mestrado, Universidade Federal de Lavras, Lavras, MG, Brasil.

5. Araújo, R. S. (2011). Implantação do Reuni na Universidade Federal do Pará: um estudo de caso do Campus Universitário de Altamira. Dissertação de mestrado, Universidade Federal do Pará, Pará, PA, Brasil.

6. Arruda, L.B. (2011). Expansão da educação superior: uma análise do programa de apoio aos planos de reestruturação e expansão das universidades federais (REUNI) na Universidade Federal de Pernambuco. Tese de doutorado, Universidade Federal de Pernambuco, Recife, PE, Brasil.

7. Bardin, L. (2011). Análise de conteúdo. (L. A. Reto \& A. Pinheiro, Trad.) São Paulo, SP: Edições 70, Livraria Martins Fortes (obra original publicada em 1997).

8. Bourdieu, P. (1994). O campo científico. In: R. Ortiz (Org.). Pierre Bourdieu/Sociologia. São Paulo, SP: Ática.

9. Brasil. (2003). Ministério do Planejamento, Orçamento e Gestão. Secretaria de Gestão. Gestão pública para um Brasil de todos: um plano de gestão para o Governo Lula. Brasília, DF: MPO.

10. Coelho, M. J. (2012). A política de assistência estudantil e a contrarreforma universitária: estudo sobre o programa de moradia 
universitária na Universidade Federal do Ceará. Dissertação de mestrado, Universidade Federal do Ceará, Fortaleza, CE, Brasil.

11. Cohen, E. \& Franco, R. (1993). Avaliação de projetos sociais. Rio de Janeiro: Vozes.

12. Coordenação Nacional de Entidades pela Renovação do Reuni. (2009). O Livro Cinza do Reuni - dossiê denúncia das consequências do REUNI. Recuperado em 20 de março, 2015, de: <http://www.senado.gov.br/comissoes/CE/AP/AP20090422_REUNI Carolina

13. PinhoeMa\%C3\%ADra\%20Gentil-b.pdf> Acesso em: 05 out. 2016.

14. Cotta, T. C., (1998). Metodologia de avaliação de programas sociais: análise de resultados e impactos. Revista de Serviço Público. (a.49, n. 2, pp.105-126) Brasília, DF: RSP.

15. Draibe, S. M. (2001). Avaliação de implementação: esboço de uma metodologia de trabalho em políticas públicas. In M.C. R. N. Barreira \& M.C.B. Carvalho (Orgs.). Tendências e perspectivas na avaliação de políticas e programas sociais. São Paulo, SP: IEE/PUC.

16. Decreto $n^{\circ}$ 6.096, de 24 de abril de 2007. (2007). Institui o Programa de Apoio aos Planos de Reestruturação e Expansão das Universidades Federais - REUNI. Diário Oficial da República Federativa do Brasil, Brasília, DF, Seção 1, p.7.

17. Gregório, J.R.B. (2011). Politica de pessoal docente do governo Lula: uma análise do REUNI na UFF e seus desdobramentos. Dissertação de mestrado, Universidade Federal Fluminense, Rio de Janeiro, RJ, Brasil.

18. LUGÃO, R. G. (2011). Consequências, limites e potencialidades na implementação do Programa REUNI em IFES de MG: um estudo multicaso. Dissertação de mestrado, Universidade Federal de Viçosa, Viçosa, MG, Brasil.

19. Oliveira, A. J. (2013). Programa REUNI nas instituições de ensino superior federal [IFES] brasileiras: um estudo da eficiência operacional por meio da análise envoltória de dados [DEA] no periodo de 2006 a 2012. Dissertação de mestrado, Universidade Federal do Paraná, Curitiba, PR, Brasil.

20. Pereira, L. C. B. (1998). Reforma do Estado para a cidadania: reforma gerencial brasileira na perspectiva internacional. São Paulo: Editora 34; Brasília: ENAP.

21. Pereira, R.L.A. (2012). Programa de apoio a plano de reestruturação e expansão das universidades federais brasileiras (REUNI): repercussões na expansão da UFRN. Dissertação de mestrado, Universidade Federal do Rio Grande do Norte, Natal, RN, Brasil. 
22. Silva, A. M. (2011). Planos de Reestruturação e Expansão das Universidades Federais: o Reuni em Mato Grosso do Sul. Dissertação de mestrado, Universidade Federal da Grande Dourados, Dourados, MS, Brasil.

23. Silva, P. A. (2013). O Reuni na UFJF: um estudo sobre os principais desafios enfrentados pelos gestores. Dissertação de mestrado, Universidade Federal de Juiz de Fora, Juiz de Fora, MG, Brasil. 